\title{
Measuring Interrelations of Prosperity Pillars LEADING TOWARDS SUSTAINABLE SUCCESS
}

\author{
Mirjana Radman-Funaric, Barbara Pisker \& Katarina Potnik Galic
}
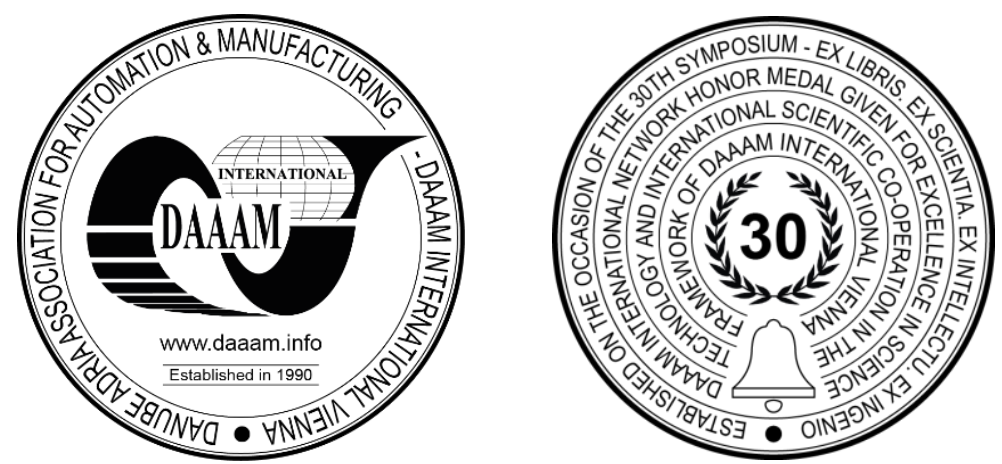

This Publication has to be referred as: Radman-Funaric, M[irjana]; Pisker, B[arbara] \& Potnik Galic, K[atarina] (2021). Measuring Interrelations of Prosperity Pillars Leading Towards Sustainable Success, Proceedings of the 32nd DAAAM International Symposium, pp.0486-0492, B. Katalinic (Ed.), Published by DAAAM International, ISBN 978-3-90273433-4, ISSN 1726-9679, Vienna, Austria

DOI: $10.2507 / 32$ nd.daaam.proceedings.070

\begin{abstract}
This paper primary goal is set to measure the interrelations between different Legatum Prosperity Index (LPI) pillars in the global frame. Enterprise Conditions pillar is set as a dependent variable, a measure of sustainable success. The paper observes the relationship towards all other pillars of LPI namely: Social Capital, Safety \& Security, Personal Freedoms, Governance, Investment Environment, Market Access and Infrastructure, Economic Quality, Living Conditions, Health, Education and Natural Environment. Pillars themselves are categorised into three main domains: Inclusive Societies, Open Economies and Empowered People aiming to ensure a holistic approach to the topic investigated. The panel sample included 167 world countries analysis for a period between 2007 and 2020 . The overall number of observations is 2338 and the analysis included two methods: bivariate correlation and hierarchical multiple linear regression (through three models). The results gained show that Investment Environment, Market Access and Infrastructure strong and positively affect Enterprise Conditions. Health, Natural Environment, Governance and Social Capital pillars also show positive, but slightly weaker relation, while Education and Living Conditions as well as Safety and Security show negative relation towards entrepreneurship. Statistically significant but weak negative link between Personal Freedom towards Enterprise Conditions is also shown.
\end{abstract}

Keywords: Prosperity index; Enterprise conditions; Social capital; Sustainability; Wellbeing

\section{Introduction}

As defined by the Legatum Prosperity Index (LPI) „Prosperity is far more than wealth; it is when all people have the opportunity and freedom to thrive. Prosperity is underpinned by an inclusive society, with a strong contract that protects the fundamental liberties and security of every individual. It is driven by an open economy that harnesses ideas and talent to create sustainable pathways out of poverty. And it is built by empowered people, who contribute and play their part in creating a society that promotes wellbeing" [1]. Prosperous society is an ideal to be reached by upgrading individual, corporation, national and global prosperity. It is not an ultimate goal by itself, but a process of social transformation, a demanding venture measured by LPI from 2007. 
The building blocks of prosperity constructed by the LPI are spread through three main domains: Inclusive societies, Open economies and Empowered people. Prosperity Index Domain Inclusive societies encompasses four key pillars: Safety and Security, Personal Freedom, Governance and Social Capital. Open economies domain includes Investment Environment, Enterprise Conditions, Market Access \& Infrastructure and Economic Quality. The dimension of Empowered people includes Living Conditions, Health, Education and Natural Environment. Each of the four pillars developed under a specific domain is subdivided furthermore into specific elements and indicators. The value of the individual element and indicator contained in the overall prosperity is the result of the data specified in The Legatum Institute [2].

The purpose of this study is to measure the interrelations between different LPI pillars in the global frame enabling their practical implications in future creation of sustainably successful socio-economic environments. Enterprise Conditions pillar is considered a dependent variable in this paper, chosen as a prosperity determinant and a measure of sustainable success due to the advantages at the disposal of the nation and the local community as noted by Porter [3] and Brakman et al. [4]. Other pillars with all their belonging elements of the prosperity index (PI) are considered independent variables. The aim of the paper is to examine different PI relationship towards Enterprise Conditions and reveal answers the research question on whether there are variables that are more closely related to Enterprise Conditions, or whether some of the pillars of PI indicate that they are a guarantee of a greater entrepreneurial activity as a foundation of the wider societal community sustainable welfare (sustainable success, wellbeing, prosperity).

If the value of socio-economic performance can be directly related to the measured entrepreneurial environment and level of entrepreneurship, numerous studies are showing the growth effect of prosperity index variables towards Enterprise Conditions. The results of Mervar study [5] showed that economic growth in the early 1960s to the late 1980s was stronger in countries with higher investment and lower public spending, with fewer price distortions, less premium on the "black" foreign exchange market, lower inflation rate, stronger involvement in international flows, higher human capital, stable socio-political conditions. According to Mervar [5], the same is confirmed by the analyses of the International Monetary Fund conducted in 1993 and 1994 in developing countries. The subject of discussion is always which of the combinations of these instruments is the best, but in general, the above relations have not changed to date. Mervar [5] cites the distinction between the "tangible gap" of countries with a lack of capital or natural resources and the "gap of ideas" of countries suffering from a lack of knowledge needed to create value in a modern economy, as Romer wrote [6].

\section{Research Methodology}

\subsection{Data and variables}

The panel sample included 167 world countries in the last 14 years for a period between 2007 and 2020. All data have been taken from The Legatum Prosperity Index [7]. The value of the individual element and indicator contained in the overall prosperity is the result of the data specified in The Legatum Institute [2]. In 2019 the Business Environment pillar, measuring country's entrepreneurial environment set, its business infrastructure, barriers to innovation, and labour market flexibility, was replaced by four new pillars introduced:

- The Enterprise Conditions pillar measures the degree to which regulations enable businesses to start, compete, and expand,

- The Investment Environment pillar measures the extent to which investments are adequately protected and are readily accessible,

- The Market Access and Infrastructure pillar measures the quality of the infrastructure that enables trade, and distortions in the market for goods and services,

- Living Conditions pillar encompasses a set of conditions and circumstances that are necessary for all individuals to attain wellbeing.

In the frame of dependent variable Enterprise Conditions pillar, the following elements have been researched: Domestic Market Contestability, Environment for Business Creation, Burden of Regulation, Labour Market Flexibility and Price Distortions.

\begin{tabular}{|l|l|}
\hline LPI Enterprise Conditions elements & LPI Enterprise Conditions indicators \\
\hline \multirow{4}{*}{ Domestic Market Contestability } & Market-based competition \\
\cline { 2 - 2 } & Anti-monopoly policy \\
\cline { 2 - 2 } & Extent of market dominance \\
\hline \multirow{5}{*}{ Environment for Business Creation } & $\begin{array}{l}\text { Private companies are protected and } \\
\text { permitted }\end{array}$ \\
\cline { 2 - 2 } & Ease of starting a business \\
\cline { 2 - 2 } & State of cluster development \\
\hline
\end{tabular}




\begin{tabular}{|c|c|}
\hline & Labour skill a business constraint \\
\hline & Availability of skilled workers \\
\hline \multirow[b]{6}{*}{ Burden of Regulation } & Burden of government regulation \\
\hline & Time spent complying with regulations \\
\hline & Number of tax payments \\
\hline & Time spent filing taxes \\
\hline & Burden of obtaining a building permit \\
\hline & Building quality control index \\
\hline \multirow[b]{5}{*}{ Labour Market Flexibility } & Cooperation in labour-employer relations \\
\hline & Flexibility of hiring practices \\
\hline & Redundancy costs \\
\hline & Flexibility of employment contracts \\
\hline & Flexibility of wage determination \\
\hline \multirow[b]{2}{*}{ Price Distortions } & Distortive effect of taxes and subsidies \\
\hline & Energy subsidies \\
\hline
\end{tabular}

Table 1. PI Enterprise Conditions pillar elements and indicators

\subsection{Methods}

The primary goal of bivariate correlation analysis is to check how the set of independent variables correlates with the Enterprise Conditions (ente). The aim is also to determine whether there is an interrelation between Enterprise Conditions and any other pillar or variable is more and/or significantly more interrelated to Enterprise Conditions pillar variable. The relationship between independent and Enterprise Conditions (ente) are examined using multiple regression. The formulas for the multiple regressions can be expressed as:

$$
\text { ente }=\mathrm{a}+\beta_{1} \text { soci }+\beta_{2} \text { safe }+\beta_{3} \text { pers }+\beta_{4} \text { gove }+\beta_{5} \text { inve }+\beta_{6} \text { mark }+\beta_{7} \text { econ }+\beta_{8} \text { livi }+\beta_{9} \text { heal }+\beta_{10} \text { educ }+\beta_{11} \text { envi }+e
$$

where Enterprise Conditions is dependent variable, and others are independent variables, $e$ is the error term involved in using the linear model to predict the value of $\mathrm{Y}, a$ is the intercept of the slope, and $\beta$ is the coefficient of the independent variable [8].

The first multiple regression model in Table 3 includes three independent variables: Economic Quality, Market Access and Infrastructure and Investment Environment, variables most commonly considered directly related to entrepreneurship in the frame of PI Open Economy domain. Sources and weights of each indicator are contained within The Legatum Institute [2]. Model 2 in the Table 3 adds four new variables: Living Conditions, Health, Education and Natural Environment, compounding the PI Empowered People domain. Sources and weights of each indicator of the Empowered people domain are contained within The Legatum Institute [2]. Model 3 adds additional four new variables: Safety and Security, Personal Freedom, Governance and Social Capital, seen as the societal, political and cultural surrounding. Sources and weights of each indicator of the Empowered people domain are contained within The Legatum Institute [2].

\section{Results and discussion}

Table 2 presents descriptive statistics for all variables included in the study. The number of observations is 2338 . No standard deviation is greater than the mean, although descriptive statistics suggest that the sample is diverse. The greatest deviation from the average among the countries of the world was noted for the variables Market Access and Infrastructure, 37\%, Governance 36,5\%, Personal Freedom, 36\% and Education 35\%, and the least for the variables Natural Environment, $15,6 \%$, Health 18,8\%, Social Capital 18,9\%. Enterprise Conditions variable deviates from the average $27 \%$, where the highest value of the index is 88 and the lowest 19.7. The deviation from the mean value of the total PI is $23.8 \%$ while $50 \%$ of the countries in the world have PI index values between 45.8 and 65.6 and the Interquartile range of index values is 19.8 .

The correlation matrix reveals that all the variables are significant at a $1 \%$ level. The correlation coefficient between some variables is greater than 0.8 , which might be a sign of multi-collinearity between independent variables. Multicollinearity is expected in the relation between overall PI and pillars due to individual PI results and is eliminated by investigating the relationship between the independent variables and the dependent variable Enterprise Conditions using multiple regressions. 


\begin{tabular}{|l|l|l|l|l|l|l|l|}
\hline Descriptive Statistic & N & Mean & St. Dev. & Min & Pctl (25) & Pctl (75) & Max \\
\hline PI & 2,338 & 56.2 & 13.4 & 27.8 & 45.8 & 65.6 & 84.5 \\
\hline Safety and Security & 2,338 & 67.2 & 15.9 & 14.5 & 59.1 & 78.4 & 96.1 \\
\hline Personal Freedom & 2,338 & 53.5 & 19.3 & 11.0 & 38.1 & 66.9 & 93.9 \\
\hline Governance & 2,338 & 50.1 & 18.3 & 12.6 & 37.8 & 60.2 & 91.0 \\
\hline Social Capital & 2,338 & 51.4 & 9.7 & 19.8 & 45.1 & 56.8 & 81.6 \\
\hline Investment Environment & 2,338 & 52.1 & 15.2 & 22.3 & 39.7 & 62.8 & 87.0 \\
\hline Enterprise Conditions & 2,338 & 53.3 & 14.4 & 19.7 & 43.2 & 62.4 & 88.0 \\
\hline Market Access and Infrastructure & 2,338 & 49.3 & 18.3 & 14.9 & 33.2 & 65.2 & 88.2 \\
\hline Economic Quality & 2,338 & 50.6 & 13.2 & 21.9 & 40.4 & 60.5 & 83.0 \\
\hline Living Conditions & 2,338 & 67.3 & 21.0 & 17.2 & 48.8 & 84.9 & 97.1 \\
\hline Health & 2,338 & 67.2 & 12.6 & 29.9 & 57.9 & 76.8 & 86.8 \\
\hline Education & 2,338 & 57.0 & 20.1 & 10.4 & 41.6 & 73.6 & 91.5 \\
\hline Natural Environment & 2,338 & 55.2 & 8.6 & 29.5 & 49.5 & 60.2 & 78.9 \\
\hline
\end{tabular}

Table 2. Descriptive Statistics

The highest correlation of the PI index is with the Investment Environment $(\mathrm{r}=0.95)$, Market Access and Infrastructure $(r=0.95)$, Governance $(r=0.94)$, and the lowest with Social Capital $(r=0.66)$ and Natural Environment $(r$ $=0.67)$. Enterprise Conditions are very strongly related to PI index $(r=0.91)$, Investment Environment $(r=0.93)$ and Governance $(\mathrm{r}=0.92)$. Enterprise Conditions correlate least with the Natural Environment $(\mathrm{r}=0.55)$, and the variables in the Inclusive societies group; Social Capital $(r=0.64)$, Safety and Security $(r=0.66)$, Personal Freedom $(r=0.67)$.

Table 3. presents the result from the multiple regression on the three models outlined above. The overall fit of the models measured by the Adjusted R2 is very high. It ranges between 0.87 and 0.93 . In other words, it seems that the models explain much of the variance in the dependent variable.

\begin{tabular}{|c|c|c|c|}
\hline \multicolumn{4}{|c|}{ Dependent variable: ‘Enterprise Conditions` } \\
\hline & (1) & $(2)$ & (3) \\
\hline \multirow[t]{2}{*}{$\begin{array}{l}\text { Investment } \\
\text { Environment }\end{array}$} & $0.737^{* * * *}$ & $0.688^{* * *}$ & $0.269^{* * *}$ \\
\hline & $(0.021)$ & $(0.019)$ & $(0.020)$ \\
\hline \multirow[t]{2}{*}{$\begin{array}{l}\text { Market Access and } \\
\text { Infrastructure }\end{array}$} & $0.120^{* * *}$ & $\mathbf{0 . 3 8 6}^{* * *}$ & $0.395^{* * *}$ \\
\hline & $(0.017)$ & $(0.020)$ & $(0.016)$ \\
\hline \multirow[t]{2}{*}{ Economic Quality } & 0.010 & $0.066^{* * * *}$ & $-0.045^{* * *}$ \\
\hline & $(0.019)$ & $(0.018)$ & $(0.015)$ \\
\hline \multirow[t]{2}{*}{ Living Conditions } & & $-0.213^{* * *}$ & $-0.200^{* * * *}$ \\
\hline & & $(0.017)$ & $(0.014)$ \\
\hline \multirow[t]{2}{*}{ Health } & & $\mathbf{0 . 0 3 8}^{* * *}$ & 0.029* \\
\hline & & $(0.019)$ & $(0.016)$ \\
\hline \multirow[t]{2}{*}{ Education } & & $-0.073^{* * * *}$ & $-0.056^{* * * *}$ \\
\hline & & $(0.015)$ & $(0.013)$ \\
\hline \multirow[t]{2}{*}{ Natural Environment } & & $0.024^{*}$ & -0.038 **** \\
\hline & & $(0.014)$ & $(0.014)$ \\
\hline \multirow[t]{2}{*}{ Safety and Security } & & & $-0.041^{* * *}$ \\
\hline & & & $(0.008)$ \\
\hline \multirow[t]{2}{*}{ Personal Freedom } & & & $-0.142^{* * * *}$ \\
\hline & & & $(0.010)$ \\
\hline
\end{tabular}




\begin{tabular}{|l|c|c|c|}
\hline Governance & & & $\mathbf{0 . 5 3 5}^{* * *}$ \\
\hline & & & $(0.019)$ \\
\hline Social Capital & & & $\mathbf{0 . 1 2 5}^{* * *}$ \\
\hline & & & $(0.011)$ \\
\hline Constant & $8.515^{* * *}$ & $9.669^{* * *}$ & $16.039^{* * *}$ \\
\hline & $(0.485)$ & $(1.022)$ & $(0.877)$ \\
\hline Observations & 2,338 & 2,338 & 2,338 \\
\hline $\mathrm{R}^{2}$ & 0.868 & 0.891 & 0.930 \\
\hline Adjusted R & 0.867 & 0.891 & 0.930 \\
\hline Residual Std. Error & $5.244(\mathrm{df}=2334)$ & $4.762(\mathrm{df}=2330)$ & $3.819(\mathrm{df}=2326)$ \\
\hline F Statistic & $5,100.286^{* * *}(\mathrm{df}=3 ;$ & $2,723.035^{* * *}(\mathrm{df}=7 ;$ & $2,811.880^{* * *}(\mathrm{df}=11 ; 2326)$ \\
\hline Note: & $2334)$ & $2330)$ & ${ }^{*} \mathrm{p}<0.1,{ }^{* *} \mathrm{p}<0.05,{ }^{* * *} \mathrm{p}<0.01$ \\
\hline
\end{tabular}

Table 3. Results of hierarchical multiple linear regression

Table 3 shows results from the multiple regression of Enterprise Conditions and 12 pillars of prosperity. The overall fit of the model measured by Adjusted R2 is fairly high in all three cases and close to 1 . This means that the model explains much of the variance in the dependent variable.

The results from the first model suggest that Investment Environment with 0.737 strong and positively affect Enterprise Conditions $(\mathrm{p}<0.01)$. This result is expected because investment environment is considered highly related to the enterprise conditions. Market Access and Infrastructure, 0.120 also positively affect Enterprise Conditions, but lower ( $\mathrm{p}<0.01)$. Both results are following Mervar survey results [5]. Compared to the results from Radman-Funaric, Pisker, Radman [9] for EU countries Market Access and Infrastructure influence is lower at the global level than in the EU countries $(\beta=0.706, p<0.01)$. The result is expected as Market Access and Infrastructure elements valued combine Communications, Resources, Transport, Border Administration, Open Market Scale, Import Tariff Barriers, Market Distortions which favour EU countries in regard to its common (single) market policy when compared to the rest of the world [2]. Surprisingly, Economic Quality is insignificant and does not affect the Enterprise Conditions. The same result was gained in the research encompassing EU countries by Radman-Funaric, Pisker, Radman [9]. Overall, Fiscal Sustainability, Macroeconomic Stability, Productivity and Competitiveness, Dynamism and Labour Force Engagement do not affect the level of entrepreneurial activity neither in the EU countries nor in the countries of the world.

The results in Model 2 included the variables from the first model, adding the second pillar group to the analysis: Living Conditions, Health, Education, and Natural Environment. The exhibit shows all independent variables are statistically significant. By adding those variables to the regression, no significant change in impact of the first group of variables on Enterprise Conditions was observed. The impact of new variables is strong and positively affect 0.688 Enterprise Conditions ( $<<0.01$ ), Market Access and Infrastructure gained 0.386, and unlike the first model Economic Quality becomes statistically significant $(\beta=0.066, p<0.01)$. Living Conditions is, as expected, negativly interrelated to Enterprise Conditions $(\beta=-0.213, \mathrm{p}<0.01)$. As institutional environment is a societal legacy, economic growth does not ultimately reach societys sustainable targets and is not necessarily directly related to economic and societal quality in general, especially in underdeveloped countries as noted by Prasetyo and Kistanti [10].

Unexpectedly, Education variable also shows negative and statistically significant interrelation $(\beta=-0.073, p<0.01)$ towards Enterprise Conditions. This interconnection could be explained thou through the sociological theory of a marginal man developed by Park, R.E. (1928) claiming how profession, institutional embedded individual (nowadays also highly educated) is less likely to develop an innovative and entrepreneurial mind, therefore development of new business forms or the opening up of new market opportunities may not be as sensitive to an increasing educational requirement. Empirical research conducted by Collins and Moore in 1970 [11] and Channon in 1979 [12] also show how entrepreneurs often come from disadvantaged background, humble origins and receive an education through secondary school only. Therefore, this thesis can explain the findings from the Model 2. Health $(\beta=0.038, p<0.5)$ and Natural Environment $(\beta$ $=0.024, \mathrm{p}<0.1)$ show slightly smaller interrelation towards Enterprise Conditions.

Comparing the results gained with the EU research results Radman-Funaric, Pisker, Radman from 2021 [9] significant differences are observed. EU data analysis show only two elements are statistically significant $(\mathrm{p}<0,01)$, Natural Environment (-0.068) and Education (0.440) with different sign then in world observed sample. In the countries of the world, the statistical significance of these variables is somewhat smaller, but while Education in the EU is positively related to Enterprise Conditions, in the world this correlation is negative. The results are at odds with the results revealed by Romer [6] and Mervar [5]. The results may suggest that despite poorer education in developing and underdeveloped countries there is a better Environment for Business Creation, higher Labour Market Flexibility and lower Burden of Regulation, which are included in the assessment of overall Enterprise Conditions. Also, the Natural Environment is negatively connected in the EU and positively in the world. This result may indicate that European countries have already 
reduced the quality of the Natural Environment due to greater development, while developing and underdeveloped countries still have an unspoiled natural environment.

Lastly, the third regression model included all 12 pillars of prosperity. It is the strongest model in regard to Adjusted $R$ squared. It comprises additional four new variables grouped under the PI Inclusive Societies domain: Safety \& Security, Personal Freedom, Governance, Social Capital. All of these independent variables are statistically significant at the significance level $\mathrm{p}<0.1$, the other ten variables for which $\mathrm{p}<0.01$. This model introduced variables novelties meant a rather significant decrease of the impact of Investment Environment on Enterprise Conditions; precisely it decreased from 0.688 in $2^{\text {nd }}$ model to 0.269 in $3^{\text {rd }}$ model. This brings a key note in the discussion showing how Inclusive Societies domain does not fit in mutually positively with Investment Environment in Enterprise Conditions. This is due to the fact how globally dominant sector of production is still predominantly embedded in a domain of favouring profit before people and not jet tuned in with societal frame tailored and fitted for the rise of the Inclusive Societies domain favouring people before profit. Economic Quality and Natural Environment in second previously presented model had a positive influence to Enterprise Conditions, while in this model they take on a negative sign, which indicates that by increasing the number of independent variables, which we believe have a positive impact on the level of entrepreneurship, they give a different perspective on the prerequisites for the Enterprise Conditions development.

Safety and Security shows negative relation (-0.041) to the Enterprise Conditions in accordance to Pinazo-Dallenbach, Roig-Tierno \& Mas-TurAre [13]. Social Capital (0.125) is positively related to the Enterprise Conditions, which is partly consistent with Leonardi, Naneti, Putman [14], Fukuyama [15], Tortosa-Ausina \& Peiró-Palomino [16], Radman-Funaric [17], Borozan \& Radman-Funaric [18], Radman-Funaric [19]. Partly only, as the research is based solely on social trust or the results differ in individual elements (variables) of social capital. The same results were gained by Radman-Funaric, Pisker, Radman [9] research when analysing this impact in EU countries.

Governance is positively related to the Enterprise Conditions (0.535), as verified in the EU countries in accordance to Hardin [20] and Knack \& Keefer [21] research proving more reliable and efficient state institutions lead to greater mutual trust and respect for norms which creates a more favourable entrepreneurial environment. Surprisingly, Personal Freedom is negatively interrelated to Enterprise Conditions (-0.142) although this relation is not strong, while EU countries research [9] did not reveal interconnection inbetween Personal Freedoms and Enterprise Conditions. As Baumol noted depending on the overal societal validation frame there are two types: a society favouring productivity through economic and personal freedoms that will be rewarded with higher allocation of entrepreneurial energy to innovation. On the other hand, a society with a high level of political intervention, high level of taxation and regulation, will see more entrepreneurial energy devoted to non-productive activities such as rent-seeking [22], [23]. Nyström also finds that countries with smaller government, stronger legal system and rule of law, better protection of property rights, and fewer regulations have higher level of self-employment concluding that the overall effect of freedom on entrepreneurial activity is positive and statistically significant [24], [25].

\section{Conclusion}

Prosperity goes beyond narrow, single sided material pleasures and transcends material concerns. It resides in the quality of our lives and the health and happiness of our society. It is present in the strength of our relationships and our trust in the community. It is evidenced by our satisfaction at work and sense of shared meaning and purpose of our existence. It hangs on our potential to participate actively in the life of society. Prosperity consists in our ability to flourish as human beings - within the ecological limits of our finite planet. The challenge for our society is to create the conditions under which this is possible. It is the most urgent task of our times and our generation. The study presented through the panel sample included 167 world countries analysis for a period between 2007 and 2020. The overall number of observations is 2338 and the analysis included two methods: bivariate correlation and hierarchical multiple linear regression (through three models) The study results show that Investment Environment, Market Access and Infrastructure strong and positively affect Enterprise Conditions. Health, Natural Environment, Governance and Social Capital pillars also show positive, but slightly weaker relation, while Education and Living Conditions as well as Safety and Security show negative relation towards entrepreneurship. Statistically significant but weak negative link between Personal Freedom towards Enterprise Conditions is also shown.

Practical implications of the study presented lead towards a need for different stakeholder action (from legal framework, board managers, employees and civil society sector) in contributing towards developmental pathway in global positioning of prosperous society as a dominant category. As it is evident from the study results presented societies cannot be prosperous if undermining any of the aspects of the holistic developmental PI approaches (opened economies, empowered people, inclusive society). The time has come for the leaders to reshape the developmental list of priorities placing people and planet before greedy economies in order to keep the ecosystem balance in a humbler vision of a sustainable future to come. It is on the business leaders to enable a sustainable future success.

Study limitations oblige us to declare how results show no interconnection between Enterprise conditions and Economic quality including GDP growth. Future research call upon research towards the relationship between Enterprise Conditions and all elements of Economic quality to discover which of the specific element is not interrelated to Enterprise conditions and which one has got the strongest connection. Furthermore, the analysis would improve due to the separate elements and indicator analysis in social capital towards Enterprise Conditions influence, a task for future research. 
Since it is expected for all positive results to be closely bonded with conditions of entrepreneurship development it is necessary to select those variables that are not statistically relevant towards Enterprise conditions from the present analysis and closely check which of the variables included in the model disturb the results expected.

\section{References}

[1] Legatum Prosperity Index (2020). LPI Summary, Available from: https://www.prosperity.com/about/summary Accessed: 2021-3-15

[2] The Legatum Institute (2020). Sources and indicators used, and changes made since the 2019 index 2020 . A tool for transformation, Available from: https://docs.prosperity.com/4416/0518/8129/2020_Index_Sources_Indicators_and_Changes.pdf Accessed: 2021-315

[3] Porter, M.E. (2004). Building the microeconomic foundations of prosperity: findings from the microeconomic competitiveness index, Oxford University Press, ISBN 0195173600, 9780195173604, Oxford

[4] Brakman, S.; Garretsen, H.; Van Marrewijk, C. \& Van Witteloostuijn, A. (2006). Nations and firms in the global economy: an introduction to international economics and business, Cambridge University Press, ISBN 0521832985, Cambridge

[5] Mervar, A. (1999). "Pregled modela i metoda istraživanja gospodarskog rasta", Privredna kretanja i ekonomska politika, Vol. 9, No. 73, 1999, pp. 20-61., ISSN 1330-187X

[6] Romer, P. (1993). "Idea gaps and object gaps in economic development", Journal of Monetary Economics, Vol. 32, No. 3, 1993, pp. 543-573., ISSN 0304-3932

[7] The Legatum Institute (2020). The Legatum Prosperity Index, The 14th edition of the Legatum Prosperity Index Available from: https://www.prosperity.com/about/resources, Accessed: 2021-2-12

[8] Kamki, J. (2017). Digital Analytics: Data Driven Decision Making in Digital World, Notion Press, ISBN 978 1946556196, Chennai

[9] Radman-Funaric, M., Pisker, B. \& Radman, M. (2021). Future at Stake: Key Pillars Aggravating Croatian Pathway to Prosperity, Proceedings of 10th International Scientific Syposium Region, Entrepreneurship, Development, Osijek, ISSN 1848-9559 Leko Simic, M. \& Crnkovic, B. (Ed.), pp. 967-983., EFOS, Osijek

[10] Prasetyo, P. E. \& Kistanti, N. R. (2020). "Human capital, institutional economics and entrepreneurship as a driver for quality \& sustainable economic growth", Entrepreneurship and Sustainability Issues, Vol. 7, No. 4, pp. 2575 2589., DOI https://doi.org/10.9770/jesi.2020.7.4(1)

[11] Collins, O. F. \& Moore, D. G. (1970). The organization makers: A behavioral study of independent entrepreneurs, Appleton-Century-Crofts, ISBN 03902031229780390203120 , New York

[12] Channon, D. (1979). "Leadership and corporate performance in the service industries", Journal of Management Studies, Vol. 16, No. 2, pp. 185-201., DOI https://doi.org/10.1111/j.1467-6486.1979.tb00382.x

[13] Pinazo-Dallenbach, P., Roig-Tierno, N. \& Mas-Tur, A. (2015). Are Problems with Violence and the Lack of Public Safety a Barrier to Entrepreneurship?, Proceedings of Annual Conference of the Global Innovation and Knowledge Academy, ISBN 9783319222042 , Valencia

[14] Leonardi, R.; Nanetti R. Y. \& Putnam, R. D. (2001). Making democracy work: Civic traditions in modern Italy, Princeton University Press, ISBN 9780691037387, Princeton

[15] Fukuyama, F. (1995). Social capital and the global economy, Foreign Affairs, Vol. 74, No. 4., pp. 89-103., ISSN: 0015-7120, 2327-7793

[16] Tortosa-Ausina, E. \& P. J. Peiró (2012). "Social Capital, Investment and Economic Growth: Evidence for Spanish Provinces", Spatial Economic Analysis, Vol. 10, No. 1, pp. 102-126., Routledge

[17] Radman-Funaric, M. (2013). Osnaživanje socijalnog kapitala u cilju poticanja gospodarskog razvoja hrvatskih regija, Ph.D. Dissertation, Faculty of Economics in Osijek, J. J. Strossmayer University of Osijek, Osijek, Croatia

[18] Borozan, D. \& Radman-Funaric, M. (2016). "Social capital in Croatia: Measurement and regional distribution," Innovation: The European Journal of Social Science Research, Vol. 29, No. 4, pp. 481-505.

[19] Radman-Funaric, M. (2018). "The Trust in Institutions and Manager Association," International Journal Vallis Aurea, Vol. 4, pp. 37 - 48.

[20] Hardin, R. (1982). Collective Action, RFF Press, ISBN 9780801828195, Washington

[21] Knack, S. \& Keefer, P. (1997). "Does social capital have an economic payoff? A cross-country investigation," The Quarterly journal of economics, Vol. 112, No. 4., pp. 1251-1288., DOI https://doi.org/10.1162/003355300555475

[22] Baumol, W. J. (2010). The microtheory of innovative entrepreneurship, Princeton University Press, ISBN: 9780691145846, Princeton

[23] Hall, J.; Pulito J. \& Van Metre, B. (2012). Freedom and entrepreneurship: New evidence from the 50 states, Mercatus Centre Working Paper No. 12-13., Available from: https://www.mercatus.org/system/files/Freedom-andEntrepreneurship-Working-Paper.pdf, Acessed: 2021-2-12

[24] Nyström, K. (2008). "The institutions of economic freedom and entrepreneurship: evidence from panel data," Public choice, Vol. 136, pp. 269-282. DOI https://doi.org/10.1007/s11127-008-9295-9

[25] Nyström, K. (2008). Is Entrepreneurship the Salvation for Enhanced Economic Growth?: A review of the empirical evidence of the effect of entrepreneurship on employment, productivity and economic growth, Working Paper Series in Economics and Institutions of Inovation 143, Royal Institute of Technology, CESIS - Centre of Excellence for Science and Innovation Studies 